\title{
Enkele Ou-Testamentiese perspektiewe en die betekenis daarvan vir die bediening van die gemeente
}

\author{
J.L. Helberg \\ Departement Ou Testament \\ Potchefstroomse Universiteit vir $\mathrm{CHO}$ \\ POTCHEFSTROOM
}

\begin{abstract}
Old Testament perspectives and their significance in the ministry of the congregation

The soteriologic approach of Von Rad as well as the historical-critical approach of the Old Testament is presently regarded by many scholars as inadequate. Furthermore, there are calls for more altention 10 man's material needs and to man's ecological responsibility, as well as a call for more attention to the unity of the Old Testament. This article explores some basic alignments in the Old Testament and the way in which the theme of the kingdom of God can provide for the need created by these voices. The lines of thought are briefly drawn to the New Testament and to the implicit meaning of these lines of thought for the ninistry.
\end{abstract}

\section{Inleidend}

Ons land se omstandighede van grootskaalse heroriëıtering vra om basiese oriëntering van die bediening van die gemeente deur Woordbediening en pastorale sorg. Verder is daar belangrike resente tendense in die Ou-Testamentiese teologiese besimning wat implikasies het vir die bediening. Daar word vandag besef dat Voll Rad $(1962,1965)$ se soteriologiese benadering wat die Ou-Testamentiese teologie sterk beinvloed het, nie genoegsaam ingestel is op die hele lewe en sy problematiek nie. Dieselfde geld van die histories-kritiese benadering wat al lank die studie van die Ou Testament sterk beheers. Verder is daar stemme wat ander aksente in die Ou-Testamentiese studie vra - aksente soos seên, die mens se sosio-ekonomiese bestaall en die ekologie. Voorts het daar 'n groter besef van die eenheid van die Ou Testanent ontwikkel.

In hierdie artikel word genoemde aspekte nader bespreek en enkele basiese openbaringshistoriese gerigthede van die Ou Testament ondersoek, asook die 
wyse waarop 'n benadering van die koninkryk as deurlopende tema in die $\mathrm{Ou}$ Testament die aangeduide leemtes kan vul. Baie kortliks sal ook aandag geskenk word aan die vervulling in Christus en die betekenis wat die gerigtheid vir die bediening inhou.

\section{Resente tendense in die Ou-Testamentiese teologie}

Von Rad (1962:4 e.v.) volg 'n heilshistoriese benadering. Volgens hom is God deur Israel primêr as Verlosser gesien. Selfs waar Hy as Skepper beskryf word, is hierdie hoedanigheid ondergeskik aan dié van Verlosser. Van der Woude (1969:1-17) wys egter tereg daarop dat die klem in die Ou Testament op God as Skepper en Onderhouer van alle dinge val en dat die skepping (natuur) ter wille van homself waardeer word, en nie bloot ter wille vall verlossing nie (Job 38-39; Ps. 104). Die nadruk val in die Ou Testannent nie werklik op kerugma, die proklamasie van die heilsgeskiedenis, soos Von Rad beweer nie, naar op lering en die onderrig in die gebooie van die Here, sodat hulle in die praktiese lewe onderhou moet word

Westermann (1978:88-99) benadruk dat die klem in die Ou Testament nie net op God se verlossingswerk val nie, maar ook op God se seën; daardeur ontvang die duursaamheid van God se werk in die geskiedenis en die daaglikse lewenspraktyk 'n sterker nadruk. Verder lê Westermann (1978:138-153) nadruk op die dialogiese verhouding tussen God en mens. Van die mens se kant word die dialoog veral gevoer deur iniddel van die lofsang en die klaagsang.

Volgens Brueggemann (1972:78) moet die nadruk nie bloot gelê word op die mens as verloste wese nie maar eerder op die mens as geskape wese. Die mens het die taak oin regeerder van die skepping te wees en moet 'n kulturele taak vervul. Brueggemann (1978:185-189) wys op die leemte in die twee heersende benaderings in die studie van die Ou Testament in die afgelope tyd, naamlik die eksistensialistiese benadering wat veral met Bultmann geassosieer is, en die "magtige dade van God in die geskiedenis' wat veral deur Von Rad en Wright benadruk is. Die eksistensialistiese benadering is indiwidualisties en stel 'emansipasie' en 'betekenis' as die inens se sentrale agenda. Hierteenoor stel Brueggemann dat die probleem nie emansipasie is nie, maar 'geworteldheid', nie 'betekenis' nie, maar 'toebehorendheid', nie geskeidenheid van die gemeenskap nie, maar 'geplaas wees' (placement). Die benadering van Von Rad en Wright ooraksentueer volgens Brueggemann die skerp diskontinuiteit met die Kanaäniete en neig tot 'n eensydige antitese van ruinte-tyd, natuur-geskiedenis. Die verbond word volgens hom benadruk ten koste van die land. Brueggemann wend die landtema aan as herneneutiese sleutel tot die studie van die Ou Testament. Volgens hom vestig die landtema die aandag weer op die geloof in Jahwe as regeerder en onderhouer van die land: dit benadruk ruimtelike geskiedenis (placed history). Brueggemann het 'n sterk sosiologiese benadering en hy lê sterk klem 
op die sosio-ekonomiese problematiek, soos byvoorbeeld armoede en onderdrukking.

Santmire (1985:189-199) pleit vir 'n ekologiese herneneutiek van die geskiedenis. Volgens hom is die leemte in die gangbare benadering van die Ou Testament dat die mens in die sentrum van die hele prentjie staan en dat die res van die lewende en nie-lewende wêreld slegs die agtergrond van die drama van die menslike geskiedenis vorn.

Daar gaan meer en meer stemme op teen die histories-kritiese benadering wat lank die studie van die Ou Testament oorheers het. Hierdie benadering fragmenteer dic Ou Testament en laat nie die eenheid daarvan tot sy reg kom nie. Rendtorff (1970:105-107) wys daarop dat hierdie metode outoriteitsvry is en nie die gesag van die Woord tot sy reg laat koın nie. Dit kan slegs sê wat Christelik was, nie wat nou Christelik is nie.

Childs $(1979 \cdot 40,58-58,74)$ verwoord op sistematiese wyse die beswaar wat baie mense teen die histories-kritiese metode het. Volgens hom gebnik hierdie metode die oorspronklike bronne of die groeiproses van die teks te veel as uitgangspunt, in plaas daarvan om die kanon as finale produk te gebruik. Die teologiese refleksie van die gemeenskap wat die geskrifte gebruik het, word nie in ag geneem nie; die historiese proses wat gelei het tot die vonming van die kanon, word bloot in terme van sosiologiese, politieke en ekonomiese kragte verklaar. Childs sê dat die kanon Goddelike openbaring is, nie 'n eksistensiële geskiedskrywing wat uitdrukking gee aan Israel se selfverstaan nie

Daar was die afgelope tyd 'n neiging on 'n benadering te verny wat uitgaan van een of ander sentrale gedagte van die Ou Testament as tema (W.C. Kaiser, 1978:22-25). Weens die klem wat van verskeie kante op die eenheid van die Ou Testament gelê word, is dit verstaanbaar dat daar tans egter nie van 'n sentrale gedagte weggeskram word nie. Preuss $(1991,1992)$ gaan byvoorbeeld uit van die verkiesing in die Ou Testament, en O. Kaiser (1993:21) sluit aan by die verhouding God, mens en wêreld. W.C. Kaiser (1978:32-40) neem die belofte as uitgangspunt

\section{Die koninkryk van God in die Ou Testament}

Die voorgaande benaderings wys op sake wat om groter aksent in die studie van die $\mathrm{Ou}$ Testament vra $\mathrm{Na}$ my oortuiging word al hierdie aksente geakkommodeer in die benadering van die koninkryk van God as sentrale tema in die $\mathrm{Ou}$ Testament. Bright (1953) byvoorbeeld bou hierdie tema oortuigend uit (vgl. ook Dentan, 1972:1159-1166 vir 'n bespreking van en 'n oorsig oor die koninkryk). In hierdie andersins baie verdienstelike studie grond Bright egter sy uitgangspunt te sterk in God se heerskappy in en deur Dawid, in plaas van in en deur Adam (Helberg, 1976:1) Daardeur kry sy koninkryksbenadering, ondanks sy eie verset 
daarteen, ' $n$ te sterk ampsgerigtheid in plaas van ' $n$ gerigtheid op die gewone gelowige. Die koninkryk van God het te doen met God se heerskappy in verband met die skepping, die sondeval ell die herskepping, 'n heerskappy wat op so 'n manier uitgeoefen word dat dit uiteindelik deur almal erken sal word.

Belangrike kenmerke van die koninkryk kom veral na vore in Moses se roeping om Israel uit die slawehuis van Egipte te lei en sluit die volgende aspekte in: God heers soewerein en lewewekkend oor alle dinge en $\mathrm{Hy}$ beoefen persoonlike gemeenskap, en wel verbondsgemeenskap, met die mens. Dit doen Hy ondanks die diepe gevallenheid van die mens en die wêreld en dit geskied deur God se openbaring in sy Woord en die geskiedenis (insluitende die skepping of natuur; Helberg, 1988:4-6). Die tema van die koninkryk van God lê die klem sterk op die mens se behoefte aan verlossing van sonde en bring tegelykertyd die mens se hele bestaan in die kollig, insluitende sy stoflike en bedieningsbehoeftes en sy verantwoordelikheid teenoor God, die naaste en die skepping.

\section{Die verbondsgerigtheid in die Ou Testament}

Die verbondsgedagte neem 'n baie belangrike plek in die Ou Testannent in. Eichrodt byvoorbeeld $(1961,1967)$ bou sy hele teologie rondom hierdie begrip op. Andere wys op die voorkoms van die begrip by ander volke (vgl. McCarthy, 1973:15-107), hoewel die verbondsbenadering wel bevraagteken word. Dit raak die datering asook die aard van die verbond. Volgens Perlitt (1969:6 e.v.) dateer die verbondsgedagte by Israel eers vanaf die ballingskap. Nicholson (1986:215) steun blykbaar ten onregte hierdie gedagte. Die volgende stelling van hom is egter ter sake:

The concept of a covenant between Yahweh and Israel is ... the concept that religion is based, not on a natural or ontological ecquivalence between the divine realm and the human, but on choice .. adoption and free decision.

Kutsch (1971:342-343) sien die verbond slegs as 'n verpligting. Daarteenoor stel Nicholson (1986:210-211) tereg die bilaterale aard van dic verbond, met verwysing na onder andere Jeremia 31:31-34 (vgl. ook Eks. 24:3-8; 34:10-28, Deut. 26:17-19). Bright (1953:28-29) en Helberg (1988 4-5) beklemtoon dat die koninkryk en die verbond nie net met God se heerskappy óór die mens te doen het nie, maar veral persoonlike gemeenskap met die mens insluit. (Zimmerli, 1970:172-3 wys tereg op die 'sintetiese' denkwyse in die Ou Testament, teenoor die oorbeklemtoning van 'n enkele aspek in die verbond.)

God het nie 'n massa mense geskep nie, ook nie volke of beroepsgroepe, of ampte of 'n staat nie. Hy het een mens gemnaak, nie as 'n indiwidualis nie maar as deel van 'n paar, man en vrou (Gen. 1:26-28; Matt 19:4-6), maar log elkeen met 'n eie indiwidualiteit. Hiervan getuig die genuanseerde gebnuk van die enkelvoud en meervoud by die skepping van die mens as beeld van God in Genesis 1:27 ("God 
het die mens geskep as sy verteenwoordiger, as beeld van God het Hy die mens geskep, man en vrou het Hy hulle geskep"). Man en vrou is elkeen nie maar 'n blote onderdeel van 'n kollektiwiteit nie. Wheeler Robinson (1936:49) het die begrip corporate personality geyk waarvolgens 'n enkeling verteenwoordigend is van die groep. Hierdie noue verband met die groep neem egter niks daarvan weg dat die Ou Testament die mens tegelykertyd as 'n indiwidu sien nie. Hierdie siening blyk onder meer uit die eis on die naaste lief te hê soos jouself (tweede persoon enkelvoud; vgl. Vriezen, 1966:417-419 vir 'n weerlegging van die stelling dat die indiwiduele element eers laat in Israel ontstaan het). Verder blyk die beklemtoning van die mens as individu uit die indiwiduele aanslag van talle Psalms (Ps. 42, 43, 51, ens.) en uit die profete se nadnuk op die eis om persoonlike bekering (Jes. 55:7; Jer. 25:5; Eseg. 18:21; 33:19). Verder, God maak persoonlike bemoeienis met persone, soos Josef en Rut (Gen. 37, 39-45; 1 Sam. 1:1-2:12; Rut 1-4; vgl. ook Wright, 1983:197-201).

In die Ou Testament is die bediening, soos reeds gesien, nie bloot geestelik van aard nie. God wil ook deur konkrete dinge en handelinge gedien word, soos deur offerandes, ander kultiese handelinge en seremonies en feeste (Ps. 4:6; 122; 150; vgl. ook Preuss, 1992:226-232 oor die betekenis van die Ou-Testamentiese kultus en die probleme daar rondom). Die Psalms is vol bewondering vir die samekoms van gelowiges vir hierdie godsdiensbeoefening voor die Here (Ps. 122; 135; 146150). Tydens die samekoms kan hulle hulle hart voor Hom uitstort in klaagsang en lofsang (Ps. 38; 47, 100; 130) en word hulle bewus gemaak van die verbondsvoorregte en verpligtinge (Ps. 81;84;89). Die profete beklemtoon veral die hartsgesteldheid in hierdie diens (Mayer, 1981:466-467; De Moor, 1975:32-33). Verder benadruk hulle die beoefening van reg en geregtigheid in die daaglikse lewe, want daarsonder het hierdie godsdiensbeoefening geen waarde nie. Die verbondsverhouding was gevolglik nie beperk tot die kultus nie, maar het die hele lewe omvat. Daar is konkreet aandag gegee aan die behoeftes bime die destydse omstandighede, veral dié van mense in nood: armes, weduwees, weeskinders, onderdruktes en vreemdelinge (Duquoc, 1992:2, 3; Gerstenberger, 1992:13-20). Só moet die bediening vandag ook die hedendaagse behoeftes betrek.

Die bediening moet nie sy uitgangspunte hê in sosialisme, nasionalisme en internasionalisme, gesien as basiese en beheersende lewensbenaderings nie, maar in die mens as beeld van God en tegelykertyd gevalle sondaar wat behoefte het aan God se genade en sorgende liefde. Bediening moet dus primêr indiwidueel en persoonlik wees, hoewel nie indiwidualisties gerig nie. Die bediening moet steeds veral die verbondsverbande in gedagte hou. Die behoefte van die egpaar en gesin mag nie opgeoffer word aan die belange van 'n onpersoonlike of abstrakte kollektiwiteit nie.

In die gerefonneerde teologie speel die verbond 'n groot rol en het die gesinsverband 'n belangrike plek in die bediening (vgl. ook Gen. 17:7, Hand 2:39). Die 
gesinsgerigtheid of groepsgerigtheid van die verbond kan wel verabsoluteer word. Dan word daar nie aan enkelinge in die gesin aandag gegee nie, of 'n vrou word byvoorbeeld nie as selfstandige enkeling in gebede betrek nie maar net as 'sy wat haar man bystaan'. Gebede kan verder so gesinsgerig wees dat daar net vir die vaders, moeders en kinders gebid word, terwyl vrygeselle en vrygesellinne wat in die erediens sit, heeltemal geïgnoreer word.

\section{Persoonsgerigtheid in die Ou Testament}

Die Ou Testament lê sterk klem op God as Persoon, op die persoonlike verhouding tussen God en mense en op hulle onderlinge verhoudinge. Die Bybelse God is nie 'n blote mag of krag nie, ook nie bloot 'n verre kontroleerder van natuurprosesse en gebeurtenisse nie; Hy is die Skepper en Onderhouer van alle dinge. Alles bestaan on Hom te eer (Ps. 19;24; 146-150). Hy het die mens uit die bodem geskep, maar as 'n besondere skepsel in 'n besondere verhouding inet Hom. Die mens is beeld van God, kind van God met die opdrag on oor die aarde te heers en dit te bewerk. Die mens se volle bestaan is ter sprake: materieel en geestelik.

Salomo se beroemde keuse was on wysheid te hê sodat hy sy werk on oor God se volk te regeer, goed kon uitvoer ( I Kon. 3). Hierdie keuse raak dus sy hele lewe in al sy fasette en dit vereis 'n volgehone persoonlike verhouding met God. Die rede waarom Salomo uiteindelik misluk het, was dat hy die wysheid verabsoluteer het. Anders as aan die begin het hy die wysheid as iets op sigself gehanteer en dit nie voortdurend van die Here afgesmeek nie. Die verhouding tot God is dus nie verdiskonteer nie, sy hart was me meer volkome met die Here soos die hart van sy vader Dawid nie (1 Kon. 11:4-11).

Die belangrikheid van hierdie verhouding en ander verhoudinge blyk by die begin van die mens se bestaan. In die kennisboom, waannee die mens se lyding verbind word, gaan dit nie bloot on die vrugte nie, maar om die verhouding wat die mens in sy hantering van die boom met God beoefen (Gen. 2-3, vgl veral 3:11: "Hoe het jy te wete gekom dat jy kaal is? Het jy tog nie van die boom geëet waarvan Ek jou verbied het on te eet nie?"). Die motivering vir die doodstraf vir moord is dat ' $n$ mens die beeld van God is (Gen. 9:6). Die Dekaloog, die grondwet vir 'n mens se lewe, bestaan uit twee dele: die deel oor die verhouding tot God en die deel oor die verhouding tot die naaste. Die digterlike boeke tipeer lewenswysheid en kennis as on die Here te vrees, te dien (Job 28:28; Ps. 11:10, Spr. 1:7, Pred. 12:13). Verder, die profete lè besondere kleın daarop dat kultus en die nakoming van godsdienstige verpligtinge geen waarde het as dit nie gepaard gaan met die praktiese uitlewing van die verhouding tot God en die naaste nie, byvoorbeeld in die beoefening van reg en geregtigheid (Jes. 1:10-16, Jer. 7:37, Am. 5:18-23, Miga 6:6-8). Wat die Psalms betref, kom die verhouding tot 
God en medemens feitlik in elkeen ter sprake en word veral vyande dikwels genoem.

Israel se bure het 'n naturgodsdiens beoefen en hulle lewensbeskouing was daarom baie plekgebonde (vgl. Smith, 1989:205). Hulle gode was lokale gode, gebiedsgode of landgode en hulle aanbidding was sterk aan bepaalde plekke gebind. By sodanige plekke het die aanbidders gaan aanbid en daarheen het hulle hulle toevlug geneem in hulle lyding. Die Bybelse God is egter die Skepper van die hemel en die aarde, die Regeerder van alle dinge en plekke. Hy is die God wat oral teenwoordig is en Hom oral laat geld. Die Skrif leer dus nie 'n geosentriese werkliksheidsbenadering of lewensbenadering nie. God plaas die mens wel by dic skepping op 'n bepaalde geografiese plek, naamlik in die tuin van Eden en gee hom 'n opdrag ten opsigte van 'n gebied waarin hy geborge is en wat hy kan behartig. Tog is sy opdrag volgens die verkondiging van Genesis 1-2 'n universele opdrag: hy moet die aarde bewerk en oor die diere heers (Gen. 1:28, vgl. Van Selms, 1967:63 vir die eenlueidsverkondiging in Gen. 1-2 ondanks die verskeidenlieid). By Abraham se roepung word hy weggeroep van sy geografiese wortels en in 'n ander land geplaas (Gen. 12:1-3). Die uittog beklee in die openbaringsgeskiedenis 'n meer sentrale plek as die intog. Hoewel die beloofde land 'n belangrike plek beklec, skuif daar tussen die uitlog en die intog 'n ander, beheersende faktor in: die Tien Gebooie wat by Sinal gegee is en waarin dit gaan on die verhouding tot God en die naaste (Eks. 20, vgl. in verband met die voorgaande Helberg, 1990:37, 61-63). Hoewel daar sentrale aanbiddingsplekke was en daar groot $\mathrm{k} / \mathrm{lem}$ gelê is op Jerusalem en die tempel as aanbiddingsplek, was die oorwegings hiervoor heeltemal anders as by die heidense bure. Die klem wat soms op sentralısering gelê is, was bedoel as teenvoeter teen die afgodediens en willekeur wat onder invloed van die heidense bure by plaaslike heiligdomme ingesluip het (Vriezen, 1966:39). Sentralisering het verder gestalte gegee aan die behoefte aan gesamentlike aanbidding ter beoefening van die gemeenskap van die gelowiges.

In Jesus Christus het die persoonlike gerigtheid sy volle vervulling gekry. Die land en tempel het hulle besondere betekenis verloor en Jesus self het die sentrum van aanbidding geword ("Waar twee of drie in my Naam bymekaarkom, is Ek by hulle" - Matt. 18:19). Die verbondskind van die Nuwe Testament moet dus 'n grondliggende beslissing en keuse maak sodat sy lewe nie geosentries, materieel, nasionaal of hoe ook al is me, maar deur hierdie persoonlike faktor beheers word. Hierdie keuse is net so grondliggend vir die regte lewensbenadering en vir bediening as die keuse wat die ryk jong man moes maak (Matt. 19:16-30).

Die persoonsgesentreerdheid vereis dat bediening nie bloot tot 'n kantoor en ' $n$ studeerkamer beperk moet wees nie, maar lidmaatgerig. Die bediening moet ook uitgaan na die mense toe: die skape inoet opgesoek word (Ps. 23; Luk 15:1-7). Die gelowiges moet verder nie net opgeroep word vir samekoms in die erediens 
nie, maar vir uitlewing van die godsdiens volgens die Tien Gebooie se eis oor die verhouding tot alle mense. Jesus Clrristus het die hele Ou Testament saamgevat in die eis van die regte verhouding tot God en die naaste (Matt. 22:37-40). Hy waarsku ook ennstig dat 'kerklike aktiwiteit' waarin hierdie verhouding ontbreek, tot ontnugtering gedoem is, soos by sy wederkoms sal blyk (Matt. 25:31-46). Hierdie ontnugtering geld dus ook vir kerklike bediening wat in sodanige aktiwiteit, of selfs 'n suiwer belydenis ("Here, Here"), gesentreer word, maar waarin die diepere dimensie ontbreek (Matt. 7:21-23).

\section{Tydgerigtheid}

Terrien (1978:392) sê dat die verbondsvolk gedurende die ballingskap heilige tyd ontdek het:

Deprived of sacred space, they discovered the sacrality of time. They transfigured the present by keeping weekly the day of the Sabbath. They erased the past by observing yearly the day of atonement. They lived in the future by expecting at any moment the day of the Lord .. The Sabbath was now their temple, and became in effect a source of revelation.

Terrien oorwaardeer hiennee die 'ontdekking van die heiligheid van die tyd' in die ballingskapstyd ten koste van die voor-ballungskapstyd. Sy stelling hang egter onder meer saam met die datering van brome, soos Deuteronomium (vgl. Holwerda, 1957:19-21, 145-148, 165). Weliswaar het die verbondsvolk se mislukking die toekomsverwagtings baie sterk gestimuleer, veral onder die koningskap en die wegvoering in ballingskap. Hiern het die verwagting na die stad Jerusalem en die land onverswak gebly. Die heiligheid van hierdie plekke was egter anders as ' $n$ geosentriese heiligheid. Reeds voor die ballingskap het Israel heilige plekke 'gehistoriseer' deur die aanbidding aldaar te assosieer inet 'n historiese gebeurtenis eerder as met die plek as sodanig. Verder is die feeste 'gehistoriseer' deur hulle veral met die uttog unt Egipte te verbind (Preuss, 1992: 230, 243-244)

In die Nuwe-Testamentiese tyd word die plek-en tydgerigtheid heeltemal relatief. Die Nagmaal, wat in die plek van die Pasga gekom het, hoef nie meer op 'n bepaalde plek of 'n bepaalde tyd gevier te word nie; die persoon van Christus is die bepalende faktor. Tog verval die tyds- en plekfaktor daannee nie heeltemal sodat slegs die hier en nou belangrik word nie Die Nagnaal moet gevier word tot gedagtenis aan Christus, dit wil sê ter gedagtenis aan die historiese gebeurtenis van sy versoenende sterwe (Luk 22:19) en aan die dag wamneer Hy die nuwe wyn saam met die gelowiges in die koninkryk van sy Vader sal drink (Matt. 26:29). Daannee kom daar 'n eskatologiese perspektief wat die bediening hier en nou 'n besondere dringendheid gee inet die oog op Christus wat kom 
Die weeklikse rusdag verkry 'n ander betekenis as die Ou-Testamentiese Sabbat en word ook op 'n ander dag gevier - op die eerste dag van die week. Die eerste dag van die week is "die dag van die Here" (Op. 1:10) en is 'n feesdag as herinnering aan die opstanding van Jesus Christus waardeur Hy Homself betoon het as die Koning oor alle dinge, ook oor lewe en dood (Rom. 1.4). Die feestelikheid van hierdie dag en die diensgerigtheid van die volgelinge van Jesus moet op hierdie dag 'n oortuigende getuienis lewer van die grootheid van God en van sy sorg vir die mense. Hierdie dag moet ook die kroon span op die hele week se lewe.

\section{Universele gerigtheid}

In die Ou Testament is daar 'n sterk antitese met die wêreld, onder andere vergestalt $\mathrm{m}$ 'n antitese met die heidense nasies. Elk van die groot profete bevat byvoorbeeld 'n hele groep profetiese verkondigings teen die nasies (Jes. 13-23; Jer. 46-51, Eseg. 25-32). Tog moet rekening gehou word met God se lewewekkende koninkryksheerskappy wat mie tot mense in een gebied of volk beperk is nic, maar mense universeel tot erkemning van God laat kom. Die vyandskap teenoor die nasies word nie basies as 'n nasionale vyandskap gesien nie. Die basiese vyandskap is die met die sonde, en dit is in die eerste plek 'n vyandskap met die sonde in 'n mens self (Gen. 1-3) en in jou verbondsgroep. Ten diepste gaan dit in die verkondiging nie om veroordeling en vernietiging nie, maar om bekering en sodoende on die erkemning van God se koninkryksheerskappy en on redding. Hierdie uitgangspunt sluit selftevredenheid uit en maak plek vir bewoënheid - hiervan is Ragab, Rut en Naäınan die Siriër duidelike voorbeelde.

In die boek Daniel is daar 'n simpatieke trek teenoor heidense konings wat selfs staatkundige vyande van die verbondsvolk was - konings soos Nebukadnesar en Darius. 'n Simpatieke ingesteldheid is bespeurbaar, ondanks die skerp veroordeling van die verwaandheid van eersgenoende (Dan. 4,6). Die boek Jona verkondig op 'n aangry pende manier die genade, barmlartigheid, lankmoedigheid en liefde van God vir heidene en sy besorgdheid oor lulle (Jona 4:2, 10-11). In Jona word 'n visie, untdaging en roeping aan die gelowige gestel wat ver buite die gewone blikveld is en selfs teen die grein van die eie benadering ingaan. Die boek Jesaja verkondig op 'n kragtige wyse God as die Skepper van hemel en aarde en daarom ook as universele God en Verlosser wie se guns oor al die nasies strek. Ook hier word 'n heidense koning, wat ander gode aanbid het en daannee voortgegaan het, naamlik Kores, op 'n gunstige manier beskryf (Jes. 45:1). Daar is 'n wyer praktiese visie vir Israel g̣eopen en hy is in 'n wyer wêreld met 'n meer genuanseerde taak geplaas as toe hy in sy voeere staatkundige selfstandigheid en afsondering kon leef. Isracl moes uitreik na ander mense toe, hoewel hulle heidene met weersinwekkende godsdienste was 
In die Nuwe-Testamentiese bedeling breek hierdie universele roeping nog verder deur en kom die gedagte van diens deur selfverloëning, soos verkondig in die gedeeltes oor die lydende dienaar in Jesaja en vervul in Christus, tot duideliker vergestalting.

Die kerke in Suid-Afrika moet hulle bediening op die lees van die voorgaande skoei. Daar sal in die toekoms ' $n$ veel sterker teenwoordigheid van ander godsdienste voorkom en hulle sal hulle veel sterker laat geld. Hierin is die roeping vir die kerke nie afsondering nie, maar verkondiging. 'n Veroordelende vyandigheid teenoor ander godsdienste as groepe mense is net so min die roeping. Veel eerder moet die gees van Jesaja se verkondiging geopenbaar word, en, in ongunstige omstandighede, dié van Daniël.

Dit hou egter nie in dat die bediening daarvan moet uitgaan dat alle mense van een gees, die skeppergees, deurdronge is en daarom kinders van God is wat Hom maar rustig in terme van die verskillende godsdienste kan aanbid nie. Hierdie tendens in kringe van die Wêreldraad van Kerke moet dus afgewys word (Helberg, 1992:532-535). Volgens Jesaja 2:1-4 sal die volke na Jerusalem toe kom om daar uit die Woord van die Here geleer te word. Hierdie Woord en die aanbidding daarvolgens is die enigste ware aanbidding van God die Skepper. Die gode wat deur Nebukadnesar en die ander heidene aanbid word, is afgode en mag nie aanbid word nie (Jes. 40:18-20,43:9; 44:6-20, Dan. 3; 6). Hulle is niks, selfs al maak hulle aanspraak op die wêreldmag waardeur die verbondsvolk oorwin is.

Tog moet daar erns gemaak word met die teenwoordigheid van die aanbidders van ander godsdienste en met die feit dat daar met hulle saangeleef moet word. So het Jesaja en Daniël gedoen. So het Jesus Christus gedoen. Die wapens om hierdie godsdienste te beveg, is veral dié van die uitlewing van die Skriftuurlike deugde van liefde en selfverloëning, soos gestel in Levitikus 19:18 en in Jesus se bergrede (Matt. 5:3-12; 43-48). Hierdie situasie stel 'n groot eis aan die bediening, veral aan die Woordbediening wat hierin praktiese leiding moet gee

\section{Verantwoordelikheid vir die skepping}

Anders as wat Von Rad (1962:4 e.v.) se soteriologiese benadering dit wil, word die skepping (natuur) in die Ou Testament ter wille van homself gewaardeer en nie bloot ter wille van verlossing nie (Job 38-39; Ps. 104; Van der Woude, 1969). Verder is die mens by die skepping nie die opdrag gegee on kultus of erediens te beoefen nie, of om hom net met geestelike sake op te hou nic, maar om oor die diere te heers en die aarde te bewerk (Gen. 1:26-28). As beeld van God is die mens heerser oor die skepping onder heerskappy van God. Verder kan gewys word op die bepalings in verband met die hersteljaar (Lev. 25) en op die OuTestamentiese belangstelling in die konkrete dinge van die gelowiges se daaglikse bestaan. Hierdie bepalings geld hetsy hulle nomade is soos die aansvaders Abra- 
ham, Isak en Jakob, hetsy hulle stedelinge is soos Salomo. Hierdie belangstelling in die daaglikse dinge kom ook baie duidelik na vore in die boek Spreuke en verder in die belangstelling in stede en hulle bouwerke (soos Jerusalem) en in die verwysing na die beoefening van ambagte of kunste soos dié van die pottebakker (Jer. 18).

Die bediening het dus ook 'n roeping in verband met sowel die ekologiese as die sosio-ekonomiese uitgangspunte wat onderliggend is aan hierdie Bybelse bepalings en om dit vir vandag te verkondig.

\section{Die dienende aard van die bediening in die Ou Testament}

Die bediening ten opsigte van die koning vra ons spesiale aandag. In die tyd van die koningskap het die koning 'n belangrike rol in die lewe van Israel gespeel en was hy op een of ander manier by die kultus of erediens betrokke (vgl. Dawid se optrede om die volk te seën ens., 2 Sam. 6:18; vgl. Seybold, 1984:943-947 vir die rol van die koning in die kultus). Daar was 'n noue verband tussen die ampte. Die koningsamp was so belangrik dat die Messiaanse profesiee sterk daarby aangesluit het, veral by die heerskappy soos deur Dawid uitgeoefen (Jes. 9:5-6; $11: 1$. 5; Jer. 23:5-6; Eseg. 34:23; 37:22-25; vgl. ook Becker, 1980:12). Gedurende die ballingskap verloor die koningskap egter sy betekenis vir goed en die koningsheerskappy word met die eskatologiese Messiasfiguur verbind. Israel bevind hom nou in 'n andersoortige rol, naamlik as 'n volk wat hom onder die volke moet handhaaf op 'n ander manier as deur staatkundige mag. Die koningskap was 'n laat en sekondêre instelling in Israel en het eers gekom nadat die basiese grondslae van Israel as verbondsvolk klaar vasgelê was: verbond, wet, volkskap en land. In die tweede deel van die boek Jesaja word die toekomstige verlosser nie in terme van 'n magtige koning of heerser geteken nie, maar as 'n dienaar (Jes. 53), en wel 'n lydende dienaar.

Die boek Daniël praat van hierdie bedeling nie as een van mag vir die verbondsvolk nie, maar as een van onderwerping en diens in God se koninkryk, 'n koninkryk wat selfs vervolging vir die getroue gelowiges inhou en van hulle volharding vereis. Die gelowiges moet hulle nie aan die samelewing onttrek nie, maar moet soos Daniel en sy vriende getrou bly. Op hierdie manier sal hulle selfs belangrike openbare poste kan beklee. Sommige van hulle sal egter hulle lewe as prys moet gee (Dan. 8:24-25; 9:26,11:35). Die boek Daniël lê dus die klem op persoonlike getuienis en optrede, in onderskeiding van eie staatkundige mag. (Dit gaan hier dus nie oor 'n 'teokratiese beweging' wat teenoor 'n meer 'geestelike' beweging in Israel se stryd onder die Siriese vervolging gestaan het nie, teenoor Plöger, 1965:30; Hanson, 1975:11, 12.)

In die verloop van die openbaringskiedenis kom die andersoortige aard van die koninkryk van God dus al duideliker na vore. In die Nuwe Testament is die 
andersoortigheid op sy duidelikste want toe het die kerk geen staatkundige selfstandigheid gehad nie. Tog het die kerk ontstaan, gegroei en gebloei. Israel het wel staatkundige bevryding verwag, maar dit het Christus juis nie vir hulle gebring of in vooruitsig gestel nie. Die gelowiges het egter perspektief gekry op die onbegrensdheid en universaliteit van God se koninkryk en van Christenwees. Hulle visie het daardeur nie in 'n wydheid vervaag of in 'n engheid verstar nie. Hulle het perspektief gekry op hulle geweldige lokale verantwoordelikheid, maar as deel van 'n groot geheel. Daar het vir hulle eenheid en balans gekom tussen hierdie twee pole wat gewoonlik in ons menslike benadering in stryd met mekaar verkeer.

Bogenoemde stand van sake het ingrypende betekenis vir die aard, omvang en gerigtheid van die bediening, want sodoende word die bediening vrygemaak van die afhanklikheid van die staat en sy ondersteuning deur wette en funksioneer die bediening meer met die krag van immerlike oortuiging (vgl. die algemene kritiek dat die Christelike teologie sedert Konstantyn die Grote te veel 'n teologie van mag was; Smith, 1989:204). Bime so 'n oortuiging word die betoning van die krag van die Heilige Gees benadruk. Deur die Heilige Gees het Christus uit die dood opgestaan; deur Hoin word mense se harte en lewens tot in die wortel verander deurdat hebsug, agterdog, vyandskap en haat verdring word deur offervaardigheid en liefde. Die bediening word minder formeel en meer persoonlik van aard en kom daardeur minder voor grense soos status-, stands-, kultuur-, volks- en ander grense te staan. Sodanige bediening konsentreer baic sterker op die grondvlak van onderlinge inenslike verhoudnge

\section{Samevatting}

Die stemme wat vra vir groter erkenning van die eenheid van die Ou Testannent, van die stoflike behoefte van mense en van verantwoordelikheid teenoor die skepping (natuur), kan almal volgens hulle regmatige plek geakkommodeer word deur 'n oop oog te hê vir die koninkryk van God as tema van die Ou Testament. Op grond van so 'n siening val die klem op die mens se persoonlike verhouding tot God, die naaste en die skepping. Die Ou Testament is tegelykertyd plaaslik en universeel gerig, en tegelykertyd gerig op die konkrete hede en eskatologiese toekoms wat aan alles koers en doel gee. Die Ou Testament is egter primêr persoonsgerig. Bediening wat uitgaan van die koninkryk, plaas die klem op die mens se geestelike en stoflike behoeftes as beeld van God maar tegelykertyd as gevalle sondaar. Hierdie mens het 'n behoefte aan grondige bekering, gemeenskap met die verbondsvolk van God in onder andere ' $n$ lof- en klaaglied, en verantwoordelikheid in liefde teenoor alle mense. Die oproep tot die beoefening van reg en geregtıgheid, veral teenoor die armes en hulpeloses, neem 'n belangrike plek in en so ook die verantwoordelikheid teenoor die skepping, dit wil sê die bevordering van die ekologie. 
Sedert die ballingskap en veral sedert die koms van Christus val die klem op die dienende karakter van God se volk of gemeente, selfs te midde van ongunstige en selfs vyandige onstandighede. Die kerk se krag lê in persoonlike oortuiging en getuienis omtrent God se mag, wat eerstens deur sy Woord en die lewewekkende krag van die Gees werk ell mense se harte en gesindlıede verander om in dankbaarlieid volgens sy gebooie te lewe.

\section{Bibliografie}

BECKER, J 1980. Messianic Expectation in the Old Testament Philadelphia Fortress

BRIGHT, J 1953 The Kingdom of God New York Abingdon

BRUEGGEMANN, W 1972 Weariness. Exile and Chaos a Motif in Royal Theology The ('alholk' Biblical Quarkerly', $3+19-38$

BRUEGgEMANN, W 1978 The Land Place as Giti. Challenge and Promise in Biblical Faith London SPCK

CHILDS, B S 1979 Introduction to the Old Testament as Scripture London SCM

DE MOOR, 1975 The Sacrafice which is an Abomination to the Lord (/n Ridderbos, N.H (opgedra aan) I.oven en geloven Amsterdam Ton Bolland p 211-226)

DENTAN. RC 1972 The Kingdom of God in the Old Testament ( $n$ Layman, C $M$ ed. The Interpreter's One Volume Commentary on the Bible London Collins p 1159. 1166 )

DUQUOC, C 1992 'Who is God?' becomes 'Where is God' The Shift in a Question (III Duquoc, C \& Floristan, C, eds W'here is God? A Cry of Human Distress London

SCM (Concilium 1992/4) p 1-10)

EICHRODT, W 19611967 Theology of the Old Testament I. Il London : SCM

GERSTENBERGER, E S 1992 'Where is God? The Cry of the Psalmists. (In Duquoc, C \& Floristan, C , eds W' Where is God' A Cry of Human Distress London SCM (Concilium 1992/4) p 11-22)

HANSON, P D 1975 The Dawn of Apocalyptic Philadelphia Fortress

HELBERG, J L. 1976 A Starting Point and Method for Old Testament Study Meaning for the New Testament and the Life of the Church RVS: Theologrcal Bullerin, 4(2) 1-27

HELBERG, J L 1988 Die Here regeer Openbaringslyn deur die Ou Testament Pretoria NG Kerkboekhandel

HELBERG, J L 1990 Die verbondsvolk se verhouding tot sy land Potchefstroom Departement Sentrale Publikasies. PU vir $\mathrm{CHO}$

HEL.BERG. J L. 1992 Die verhouding tussen land en ekumene in die Ou Testament en die betckenis daarvan vir vandag III dic.Skriflig, 26(4) 523-536

HOLWERDA. B 1957 Exegese Oude Testament (Deuteronomium) Kampen Copieerinrichting v d Berg (Oudtestamentische Voordracten, 111)

KAISER, O 1993 Der Gotl des Alten Testaments Theologie des Alten Testaments, I Grundlegung Gottingen Vandenhoeck

KAISER, W C 1978 Toward an Old Testament Theology Grand Rapids Zondervan

KUTSCH. E 1971 $b^{e} r l$ Verpflichtung (III THAT I Munchen Kaiser p 339-352)

MAYER, G $1981 \mathrm{j} / \mathrm{h}$ (/m Botterweck, G J \& Ringgren, H reds Theologisches Worterbuch zum Alten Testament, I Stuttgan Kohlhammer $p$ 460-474)

McCARTHY, D J 1973 Old Testament Covenant A Survey of Current Opinions Oxford Blackwell

NICHOLSON, E W 1986 God and His People, Covenant and Theology in the Old Testament Oxford Clarendon 
PERLITT, L. 1969 Bundestheologie im Alten Testament Neukirchen-Vluyn : Neukirchener Verlag. (Wissenschaftiche Monographien zum Alten und Neuen Testament.)

PLOGER, O. 1965 Das Buch Daniel. Gütersloh: Gerd Mohn. (Kommentar zum Alten Testament.)

PREUSS, H.D 1991. Theologie des Alten Testaments, l Stuttgart : Kohlhammer

PREUSS, HD 1992. Theologie des Alten Testaments, II Stuttgart : Kohlhammer

RENDTORFF, R. 1970 Alttestamentliche Wissenschaft und Theologie (/n Siemers, H \& Reuter, HR reds. Theologie als Wissenschaft in der Gesellschaft Gottingen Vandenhoeck p 102-117.)

SANTMIRE, HP 1985. The Travail of Nature: The Ambiguous Ecological Promise of Christian Theology. Philadelphia : Fortress

SEYBOLD, K 1984 maelaek. (In THWAT IV. Stuttgan : Kohlhammer p 933-956.)

SMITH, D.L. 1989. The Religion of the Landless: The Social Context of the Babylonian Exile. Bloomington : Meyer Stone Books

TERRIEN, S 1978 The Elusive Presence Toward a New Biblical Theology New York Harper \& Row

VAN DER WOUDE, A S. 1969. De verhouding Genesis en Exodus Kerk en Theologie, 20 1-17.

VAN SELMS, A. 1967. Genesis I Nijkerk Callenbach (Prediking van het Oude Testament )

VON RAD, G 1962. Old Testament Theology I Edinburgh : Oliver \& Boyd

VON RAD, G 1965 Old Testament Theology II Edinburgh Oliver \& Boyd

VRIEZEN, Th.C. 1966 Hoofdlijnen der theologie van het Oude Testament Wageningen Veenman

WESTERMANN, C 1978. Theologie des Alten Testaments in Grundzugen Gottingen Vandenhoeck (Grundrisse zum Alten Testament)

WHEELER ROBINSON, H. 1936 The Hebrew Conception of Corporate Personality In Werden und Wesen des Alten Testaments Zeitschrift fir die Alltestamemliche Wissenschafı, 66 49-62

WRIGHT, C.J.H 1983 Living as the People of God The Relevance of Old Testament Ethics. Leicester : Inter-Varsity

ZIMMERLI, W 1970. Erwagungen zum "Bund" Die Aussagen uber die Jahwe-b rit in Ex 19-34. (In Stoebe, H J. red. Wor -Gebot-Glaube Zurich : Zwingli Verlag p 171190.) 